\title{
Front Matter: Volume 9758
}

, "Front Matter: Volume 9758," Proc. SPIE 9758, Quantum Dots and Nanostructures: Growth, Characterization, and Modeling XIII, 975801 (17 August 2016); doi: 10.1117/12.2240433

SPIE. Event: SPIE OPTO, 2016, San Francisco, California, United States 


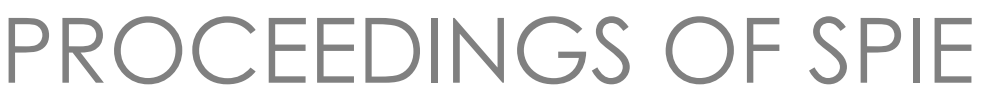

\title{
Quantum Dots and \\ Nanostructures: Growth, \\ Characterization, and \\ Modeling XIII
}

\author{
Diana L. Huffaker \\ Holger Eisele \\ Kimberly A. Dick \\ Editors
}

15-16 February 2016

San Francisco, California, United States

Sponsored and Published by

SPIE 
The papers in this volume were part of the technical conference cited on the cover and title page. Papers were selected and subject to review by the editors and conference program committee. Some conference presentations may not be available for publication. Additional papers and presentation recordings may be available online in the SPIE Digital Library at SPIEDigitallibrary.org.

The papers reflect the work and thoughts of the authors and are published herein as submitted. The publisher is not responsible for the validity of the information or for any outcomes resulting from reliance thereon.

Please use the following format to cite material from these proceedings:

Author(s), "Title of Paper," in Quantum Dots and Nanostructures: Growth, Characterization, and Modeling XIII, edited by Diana L. Huffaker, Holger Eisele, Kimberly A. Dick, Proceedings of SPIE Vol. 9758 (SPIE, Bellingham, WA, 2016) Six-digit Article CID Number.

ISSN: 0277-786X

ISSN: 1996-756X (electronic)

ISBN: 9781628419931

Published by

SPIE

P.O. Box 10, Bellingham, Washington 98227-0010 USA

Telephone +1 3606763290 (Pacific Time) · Fax +1 3606471445

SPIE.org

Copyright (C) 2016, Society of Photo-Optical Instrumentation Engineers.

Copying of material in this book for internal or personal use, or for the internal or personal use of specific clients, beyond the fair use provisions granted by the U.S. Copyright Law is authorized by SPIE subject to payment of copying fees. The Transactional Reporting Service base fee for this volume is $\$ 18.00$ per article (or portion thereof), which should be paid directly to the Copyright Clearance Center (CCC), 222 Rosewood Drive, Danvers, MA 01923. Payment may also be made electronically through CCC Online at copyright.com. Other copying for republication, resale, advertising or promotion, or any form of systematic or multiple reproduction of any material in this book is prohibited except with permission in writing from the publisher. The CCC fee code is 0277-786X/16/\$18.00.

Printed in the United States of America.

Publication of record for individual papers is online in the SPIE Digital Library.

\section{SPIE. DIGITAL}

Paper Numbering: Proceedings of SPIE follow an e-First publication model. A unique citation identifier (CID) number is assigned to each article at the time of publication. Utilization of CIDs allows articles to be fully citable as soon as they are published online, and connects the same identifier to all online and print versions of the publication. SPIE uses a six-digit CID article numbering system structured as follows:

- The first four digits correspond to the SPIE volume number.

- The last two digits indicate publication order within the volume using a Base 36 numbering system employing both numerals and letters. These two-number sets start with 00, 01, 02, 03, 04, 05, 06, 07 , $08,09,0 A, O B \ldots 0 Z$, followed by $10-1 Z, 20-2 Z$, etc. The CID Number appears on each page of the manuscript. 


\title{
Contents
}

\author{
$\checkmark \quad$ Authors \\ vii Conference Committee
}

SESSION 1 INAS QUANTUM DOTS

975802 A detailed investigation of strain patterning effect on bilayer InAs/GaAs quantum dot with varying GaAs barrier thickness (Invited Paper) [9758-1]

975803 InAs/GaAs quantum-dot light emitters monolithically grown on Si substrate [9758-2]

\section{SESSION 2 LARGE QUANTUM DOTS}

975809 Analysing radiative and non-radiative recombination in InAs QDs on Si for integrated laser applications [9758-8]

\section{SESSION 3 PHOTONICS APPLICATIONS AND NANOWIRES}

9758 OB Surface-plasmon-enhanced photoluminescence of quantum dots based on open-ring nanostructure array [9758-10]

9758 OE Growth of high-quality self-catalyzed core-shell GaAsP nanowires on Si substrates [9758-13]

\section{SESSION 4 NANOPARTICLES}

9758 OG Enhanced absorption with quantum dots, metal nanoparticles, and 2D materials (Invited Paper) [9758-15]

\section{SESSION 5 NANOMATERIALS}

9758 0J Plasmonically enhanced photoluminescence of nanoscale semiconductors [9758-22]

$9758 \mathrm{OL}$ Characterisation of high current density resonant tunneling diodes for THz emission using photoluminescence spectroscopy [9758-24]

\section{POSTER SESSION}

$97580 \mathrm{M}$ Crystalline phase destruction in silicon films by applied external electrical field and detected by using the laser spectroscopy [9758-25] 
$9758 \mathrm{ON}$ Structural characteristics of Au-GaAs nanostructures for increased plasmonic optical enhancement [9758-26]

975800 Magneto-optic evaluation of antiferromagnetic a- $\mathrm{Fe}_{2} \mathrm{O}_{3}$ nanoparticles coated on a quartz substrate [9758-27]

$9758 \mathrm{OQ}$ Effect of varying capping composition and number of strain-coupled stacks on In $0.5 \mathrm{Ga}_{0.5} \mathrm{As}$ quantum dot infrared photodetectors [9758-29]

9758 OR Photoluminescence blinking and spectral diffusion of single CdSe/ZnS nanocrystals: charge fluctuation effects [9758-30]

9758 OS Growth strategy to achieve mono-modal quantum dot size distribution in InAs/GaAs multi stack coupled heterostructures [9758-31]

9758 OT Diffusion impact on thermal stability in self-assembled bilayer InAs/GaAs quantum dots (QDs) [9758-32] 


\section{Authors}

Numbers in the index correspond to the last two digits of the six-digit citation identifier (CID) article numbering system used in Proceedings of SPIE. The first four digits reflect the volume number. Base 36 numbering is employed for the last two digits and indicates the order of articles within the volume. Numbers start with $00,01,02,03,04,05,06,07,08,09,0 A, 0 B . .0 Z$, followed by 10-1Z, 20-2Z, etc.

Aagesen, Martin, OE

Abbey, Grant P., ON

Abraham, Gabrielle, OJ

Ahmad, Aijaz, OS

Baba, Razvan, OL

Bajwa, Pooja, oJ

Balasubramanian, Srinath, 00

Balgarkashi, Akshay, OQ, OS

Beanland, Richard, 09, 0E

Chakrabarti, Subhananda, 02, OQ, OS, OT

Chan, Yin Thai, OG

Chen, S., 03

Cheng, Li-Jing , OB

Churchill, Hugh, OJ

Das, Debabrata, OT

Ghadi, Hemant, $0 Q$

Guchhait, Asim, OG

Herzog, Joseph B., OJ, ON

Heyes, Collin, OJ

Hogg, Richard A., OL

Huo, Suguo, OE

Ibuki, Hiroto, OR

Ihara, Toshiyuki, OR

Jacobs, Kristof J. P., OL

Jiang, Q., 03

Jurczak, Pamela, OE

Kale, Bharat B., 00

Kanemitsu, Yoshihiko, OR

Kannegulla, Akash, OB

Kim, Dongyoung, OE

Kumar, Ganapathy, 00

Liao, M., 03

Liu, Huiyun, 03, 09, OE

Liu, Ye, OB

Mahajan, Satish M., 00

Manasreh, Omar, ON

Milovzorov, D. E., OM

Mowbray, David J., 09

Mukai, Toshikazu, OL

Mukherjee, Bablu, OG

Nusir, Ahmad I., ON

Ohnishi, Dai, OL

Orchard, Jonathan R., 09

Panda, Debiprasad, 02, 0Q, OS, OT

Panmand, Rajendra, $0 \mathrm{O}$

Sanchez, Ana M., OE

Seeds, A., 03

Sehara, Navneet, 02, 0Q, OT

Shetty, Saikalash, OQ, OS
Shutts, Samuel, 09

Simsek, Ergun, OG

Singhal, Jashan, 02, OT

Smowton, Peter M., 09

Sobiesierski, Angela, 09

Stevens, Benjamin J., OL

Tang, M., 03

Tejerina, Alejandro, $0 \mathrm{~J}$

Tongbram, B., 02, 0T

Ward, Thomas, OE

Woodhead, Chris, 09

Wu, Jiang, 03, 09, OE

Young, Rob J., 09

Zhang, Yunyan, OE 
Proc. of SPIE Vol. $9758975801-6$

Downloaded From: https://www.spiedigitallibrary.org/conference-proceedings-of-spie on 26 Apr 2023 Terms of Use: https://www.spiedigitallibrary.org/terms-of-use 


\title{
Conference Committee
}

\author{
Symposium Chairs
}

Jean-Emmanuel Broquin, IMEP-LAHC (France)

Shibin Jiang, AdValue Photonics, Inc. (United States)

Symposium Co-chairs

David L. Andrews, University of East Anglia (United Kingdom)

Alexei L. Glebov, OptiGrate Corporation (United States)

Program Track Chair

Ali Adibi, Georgia Institute of Technology (United States)

Conference Chairs

Diana L. Huffaker, University of California, Los Angeles (United States) Holger Eisele, Technische Universität Berlin (Germany)

Kimberly A. Dick, Lund University (Sweden)

Conference Program Committee

Minjoo Larry Lee, Yale University (United States)

Baolai L. Liang, University of California, Los Angeles (United States)

Huiyun Liu, University College London (United Kingdom)

Zetian Mi, McGill University (Canada)

Jeffrey C. Owrutsky, U.S. Naval Research Laboratory (United States)

Adriana Passaseo, Università del Salento (Italy)

Qi Hua Xiong, Nanyang Technological University (Singapore)

Session Chairs

1 InAs Quantum Dots

Jonathan R. Orchard, The University of Sheffield (United Kingdom)

2 Large Quantum Dots

Anthony J. Bennett, Toshiba Research Europe Ltd. (United Kingdom)

3 Photonics Applications and Nanowires

Subhananda Chakrabarti, Indian Institute of Technology Bombay (India) 
4 Nanoparticles

Holger Eisele, Technische Universität Berlin (Germany)

5 Nanomaterials

Ergun Simsek, The George Washington University (United States) 